\title{
أحكام سجود السهو في الصلاة
}

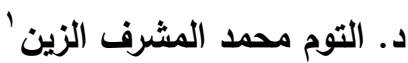

\section{مستخلص البحث:}

يناقش هذا البحث قضية أحكام سجود السهو في الصلاة وقد رأي الباحث أن طبيعة الموضوع تقتضي تقديمه في ست مطالب تتضمن تعريف سجود السهو وبيان مشروعيته وحكمه عند أصحاب المذاهب الأربعة مع بيان أسبابه ومواضعه وصفته عند الأئمة الأربعة، وفي الختام أورد الباحث نتائج البحث التي من أهمها: أن سجود السهو يكون إما فريضة أو سنة أو فضيلة أو هيئة، فلا يسجد إلا لواجب سهواً أو سنة مؤكدة فالعمد من ذلك لا يسجد له إن كان ترك واجباً أو ركناً، ولسجود السهو أسباب منى ما وجدت سجد لها، كالزيادة أو النقص أو الزيادة والنقص معاً وكذلك الثك، ومن ترك سنة من سنن الصلاة سهواً أو جهراً فإن سجود السهو بالنسبة له سنة وليس واجباً، كما أن سجود السهو قد يقع بعد السلام وقد يقع قبل السلام وذلك حسب الزيادة والنقصان، وقام الباحث بتذييل بحثة بقائمة للمصادر والمراجع التي اعتمد عليها في هذا البحث. 
مجلة معالم الدعوة الإسلامية المحكمة - العدد (السابع) - ذو الحجة ب جع اهـ/ ديسمبر ع ا ـ مم.

\begin{abstract}
The research discuss the problem of Sujood Elsahou, the researcher think that the nature of the case requires to present it in six sections which include the definition of Sujood Elsahou and clarification of it's obligatory nature in the four Fikih Schools, showing it's reasons, areas and it's describtion in the view of the four Imams, and finally the researcher presented the research results: Sujood Elsahou can be one of four, either it is Fareeda (Obligatation) or (Sunna) or (Fadeela) or (Hiyaa). The intentional neglicance is not to Sujood Elsahou, it is only for un-intentional forgetfulness if the forgeted thing is a Wajib (Duty) or Rukon it obligates Sujood Elsahou. There are reasons for Sujood Elsahou, which are for increase or decrease in the prayer or both of the two two together in the same prayer, and in addition to doubt. That who decrease a Sunna of the prayer is to do Sujood Elsahou as a Sunna not a duty. Beside Sujood Elsahou can be after or before the greeting depending upon the idea of decrease or increase of the prayer.
\end{abstract}


مقدمة:

الحمد لله رب العالمين والصلاة والسلام على أشرف الأنبياء والمرسلين

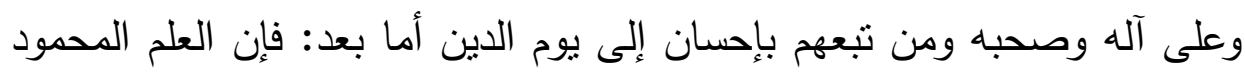

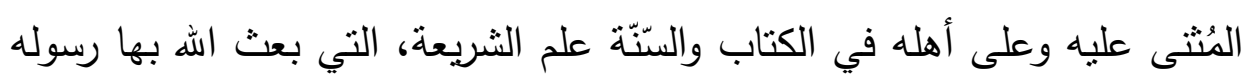

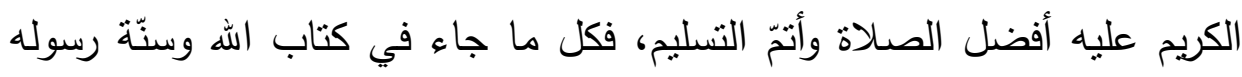

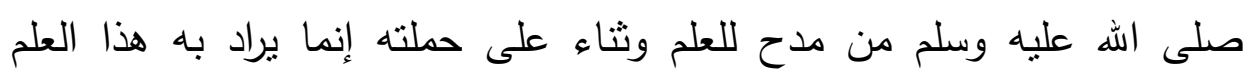

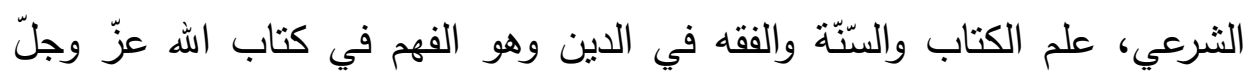
وسنة رسوله صلى اله عليه وسلم واستتباط الأحكام منهما وقد اعتىى العلماء بهذا ولها

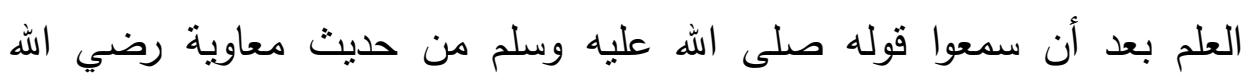

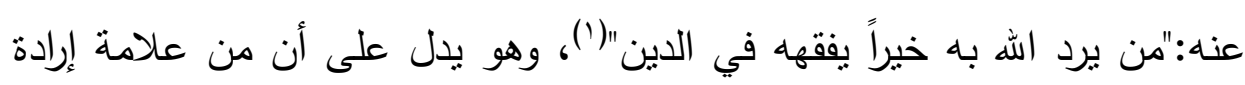

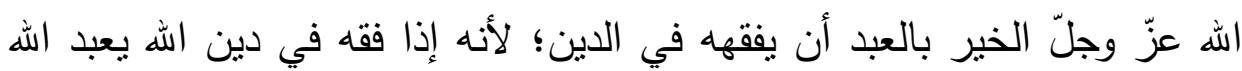

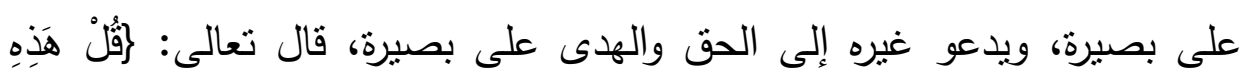

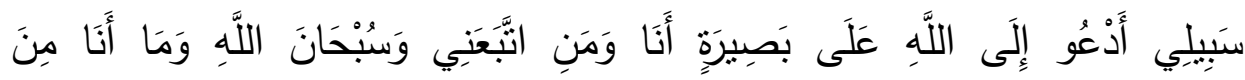
الْْشُشْرِكِنَ مشكلة البحث:

يناقش هذا البحث مشكلة السهو في الصلاة وقد أصبح من العادات

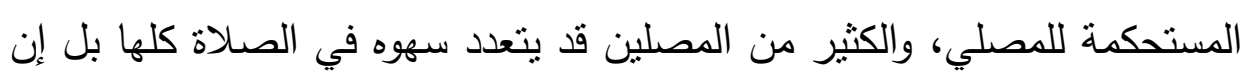

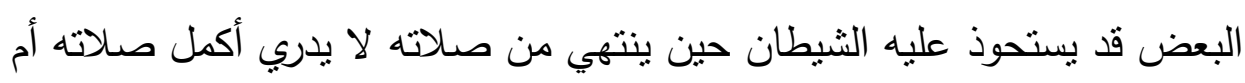

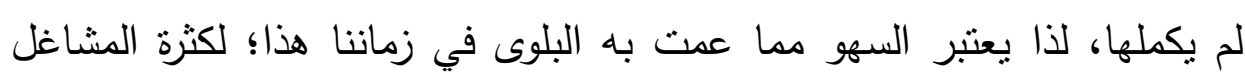

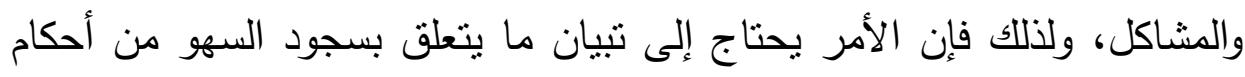

(') أخرجه البخاري في الصحيح في r - كتاب العلم بس - - باب من برد الله به خيرا يفقهه في

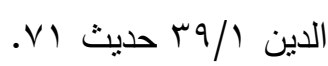


كثيرة تخفى على كثير من المصلين، بل قد لا يعرف البعض متى يسجد وما هي الأحوال التي ينبغي أن يسجد بسببها وكان ذلك من أهم الأسباب التي دفعت الباحث للكتابة في هذا الموضوع.

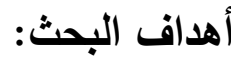

يهدف هذا البحث إلى بيان مشروعية سجود السهو التي ثبتت بأقوال وأفعال الرسول صلى الله عليه وسلم القائل:"أنما أنا بشر أنسى كما تتسون وإذا نسيت فذكروني وإذا شك أحدكم في صلاته فليتحر الصواب..."(1). وكذلك هدف البحث إلى بيان حكم سجود السهو وأسبابه التي حصل فيها تفاوت في أقوال الققهاء فمنهم من أعتبر أن حكمه واجباً والآخر بأنه سنة في الأقوال وهناك من فصل فيه فقال بوجوبه في الأفعال، وعده سُنة في الأقوال، كما تتاولت أسبابه التي تم حصرها في الزيادة والنقصان والزيادة والنقصان معاً والثك، وأخيراً هدف الباحث إلى بيان مواضعه وصفته مع خلاصة في أحكام سجود السهو

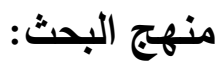

اتبع الباحث في هذا البحث المنهج الوصفي التاريخي التحليلي، ويمكن

$$
\text { توضيح ملامح هذا المنهج في الآتي: }
$$

· جمع المادة العلمية من المصادر والمراجع المعتمدة من كتب الفقه على

$$
\text { اختلاف مذاهبها. }
$$

. توثيق النصوص المقتبسة من المصادر والمراجع.

ـ توضيح الآيات وتخريج الأحاديث النبوية من مصادرها المعتمدة.

$$
\begin{aligned}
& \text { (') أخرجه مسلم في الصحيح في ه - كتاب المساجد ومواضع الصلاة } 19 \text { - باب السهو في }
\end{aligned}
$$

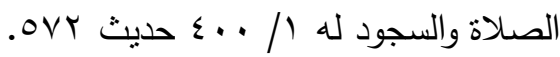




\section{• إبراز نتائج البحث.}

• إعداد قائمة المصادر والمراجع.

هيكل البحث:

اشتمل البحث على مقدمة وست مطالب وخاتمة على النحو التالي:

ـ المطلب الأول: التعريف بسجود السهو لغة واصطلاحاً.

• المطلب الثاني: مشروعية سجود السهو .

ـ المطلب الثالث: حكم سجود السهو عند أصحاب المذاهب الأربعة.

ـ المطلب الرابع: أسباب سجود السهو .

ـ المطلب الخامس: مواضع سجود السهو •

ـ المطلب السادس: صفة سجود السهو عند الأئمة الأربعة.

. الخاتمة (نتائج البحث).

.

والله المستعان 
المطلب الأول: التعريف بسجود السهو لغة واصطلاحاً

السجود لغة: - 2 - 2 - 2

يقول ابن منظور ('):"سجد"خضع، قال الشاعر: ترى الأكم فيها سجدا للحوافر

ومنه سجود الصلاة، وهو وضع الجبهة على الأرض ولا خضوع أعظم منه.والاسم السجدة، بالكسر، وسورة السجدة، بالفتح. وكل من ذل وخضع لما أمر به، فقد وضد

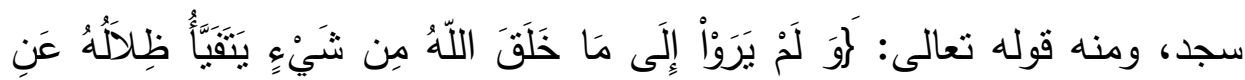

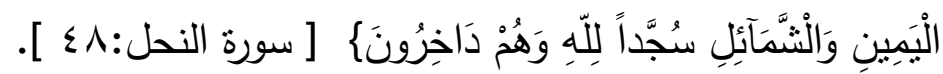
يقول ابن فارس: (السين والجيم والدال أصل واحد مطرد يدل على تطامن وذل. يقال: سجد، إذا تطامن، وكل ما ذل فقد سجد. قال أبو عمرو: اسجَدَ الرجل، إذا طأطأ رأسه وانحنى). قال حميد: فضول أزمتها أسجدت سجود النصارى

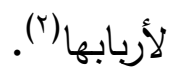
السجود اصطلاحاً: - العهاء

أكد الراغب الأصفهاني المعاني التي وردت في السجود بقوله السُّجُودُ: أصله التطامن والتذلل، وجعل ذلك عبارة عن التذلل الله وعبادته، وهو عامٌٌ في الإنسان والحيوانات والجمادات، وذلك ضربان: سجودٌ باختيار، وليس ذلك إلا

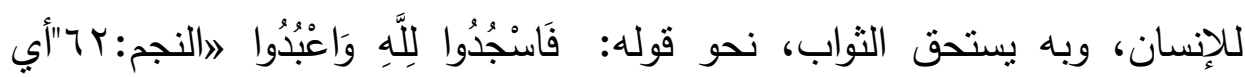
تذللوا له. وسجودٌ تسخير ، وهو للإنسان والحيوانات والنبات، وعلى ذلك قوله: وَللَّهِ

(') محمد بن مكرم بن منظور المصري: لسـان العرب دار صـادر - بيروت، الطبعة الأولى

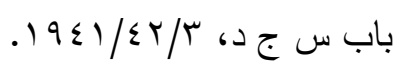

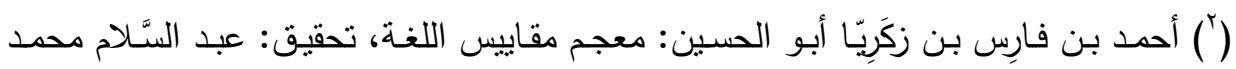

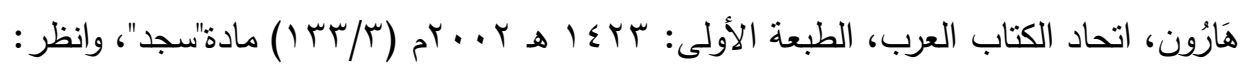

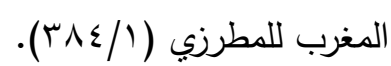




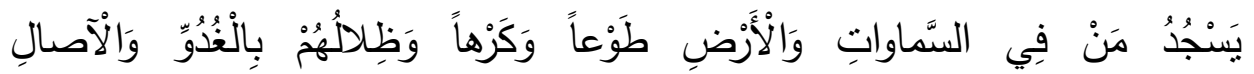

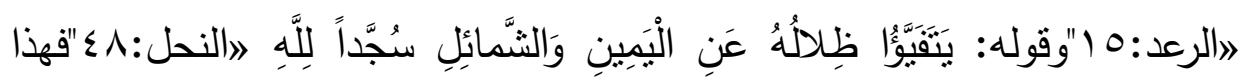
سجود نسخير، وهو الدلالة الصامتة الناطقة المنبهة على كونها مخلوقة، وأنها

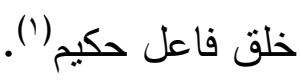
السهو في اللغة:

جاء في مادة (سها) في لسان العرب لابن منظور (ץ):"السهو والسهوة نسيان الثيء والغفلة عنه وذهاب القلب عنه إلى غيره سها يسهو سهوا وسهوا فهو ساه وسهوان، والسهو في الصلاة الغفلة عن شيء منها سها الرجل في صلاته وفي الحديث أن النبي صلى الله عليه وسلم سها في الصلاة قال ابن الأثير السهو في الثيء تركه عن غير علم والسهو عنه تركه مع العلم ومنه قوله تعالى (الذين هم عن صلاتهم ساهون) [الماعون: 0.

ويقول الثيخ ابن العثمين: سها خطأ عن غفلة، وذللك ضربان: أحدهما أن لا يكون من الإنسان جوالبه ومولداته، كمجنون سب إنسانا، والثانياني أن يكون

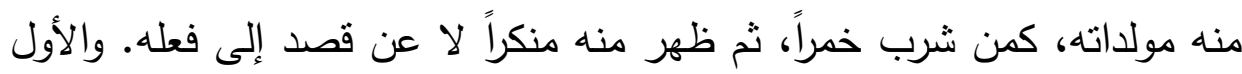

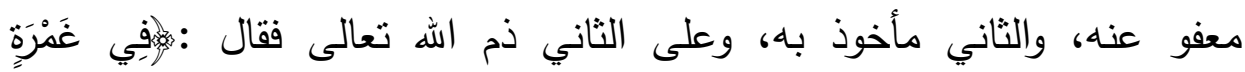

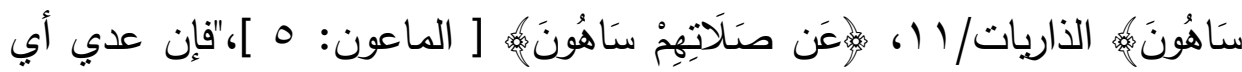

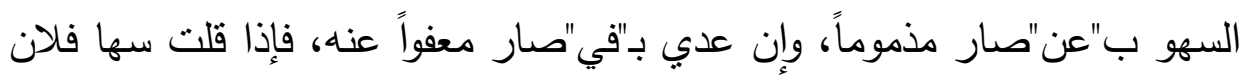

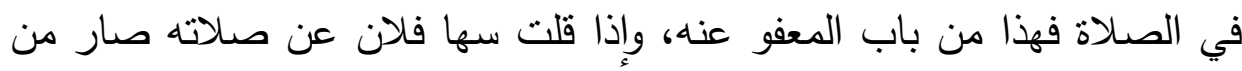

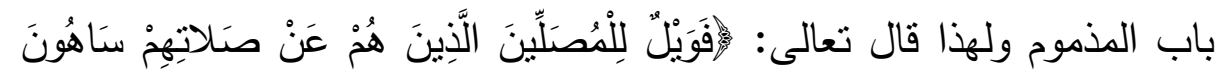

(') أبو القاسم الحسن بن محمد الراغب الاصفهاني، الدفردات في غريب القرآن، الدكتبـة

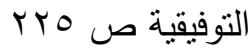

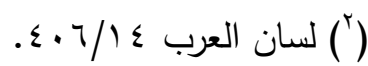


[الماعون ع-0] (') أي غافلون لا يهتمون بها ولا يقيمونها فهر على ذكر من فعلهم، بخلاف الساهي في صلاته، فليس على ذكر من فعله والمراد هنا السهو

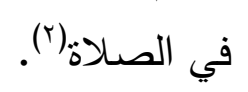

وكان سهوه في الصلاة من تمام نعمة الله تعالى على أمته وإكمال دينهم، ليقتدوا بـ فيما يشرعه لهم عند السهو، وهذا معنى الحديث المنقطع الذي في الموطأ إنما أنسى أو أنسى لأسن (r). السهو اصطلاحاً:

هو "ما يكون في أخر الصلاة أو بعدها لجبر خلل بترك مأمور به آو فعل

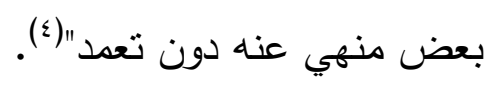
وقال زروق:"هو الذهول في الثئ أوعنه بما بؤدي إلى الإخلال به بزيادة أو نقصان أو كل منهما وكل يقع في الصلاة فيجبر بالسجود، ما لم يكثر جداً فتبطل

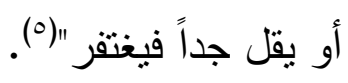

$$
\begin{aligned}
& \text { (') (') محمد بن صالح العثيمن، الثرح المتع على زاد المستقنع دار ابن الرحيد القاهرة، VVT//. }
\end{aligned}
$$

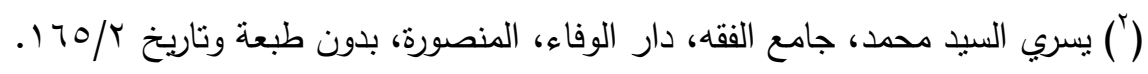

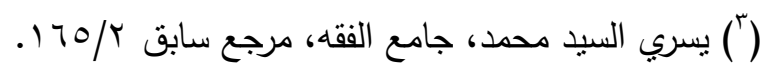

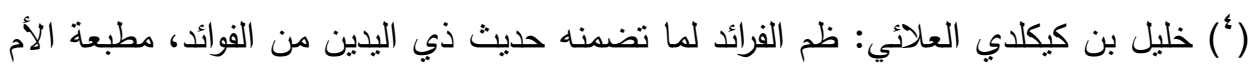

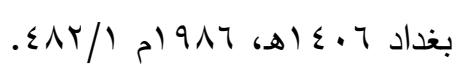

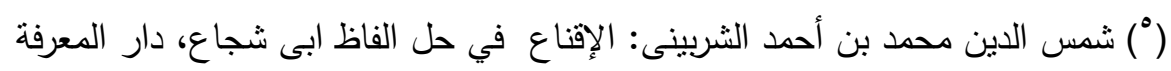

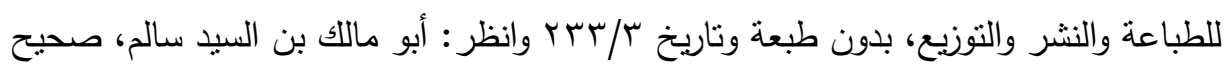

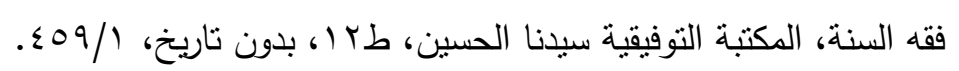




\section{المطلب الثاني: مشروعية سجود السهو}

اتفقت المذاهب على مشروعية سجود السهو لمن وقع له في الصلاة ما

جرى من النبي صلى الله عليه وسلم أو نحوه على وجه السهو .

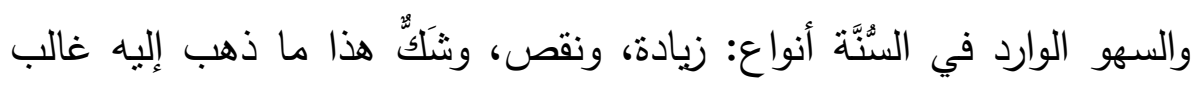

$$
\text { فقهاء المذاهب الأربعة(') }
$$

وقد صح في مشروعية سجود السهو عدة أحاديث عليها مدار أحكامه،

$$
\text { أسوقها هنا ليسهل الإحالة عليها في مسائل هذا الموضوع. }
$$

/ / حديث أبي هريرة إن رسول الله صلى الله عليه وسلم قال (إذا نودي

بالأذان أدبر الثيطان له ضراط حتى لا يسمع الأذان، فإذا قضي الأذان أقبل، فإذا ثوب أدبر فإذا قضي التثويب أقبل، يخطر بين المرء ونفسه يقول: اذكر كذا، اذكر كذا، لما لم يكن يذكر، حتى يظل الرجل ما يدري كم صلى، فإذا لم يدر

$$
\text { أحدكم كم صلى، فليسجد سجدتين وهو جالس) (r). }
$$

r/ حديث أبي هريرة رضي الله عنه قال: صلى بنا رسول الله صلى الله عليه وسلم إحدى صلاتي العشاء إما الظهر وإما العصر فسلم في الركعتين ثم أنى هـي جذعا في قبلة المسجد فاستتد إليها وخرج سرعان فقام ذو اليدين فقال يا رسول الله أقصرت الصلاة أم نسيت فنظر النبي صلى الله عليه وسلم يميناً وشمالاً فقال ما

(') القاضي أبو محمد عبد الوهاب بن علي بن نصر الثطلبي المالكي: التلقين في الفقه المالكي،

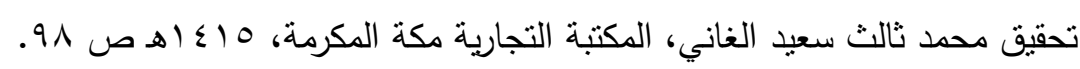

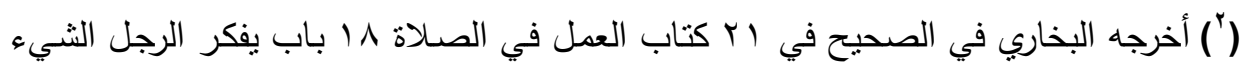

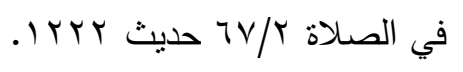


يقول ذو اليدين؟! قالوا صدق لم تصل إلا ركعتين فصلى ركعتين وسلم ثم كبر ثم

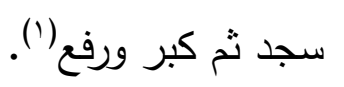

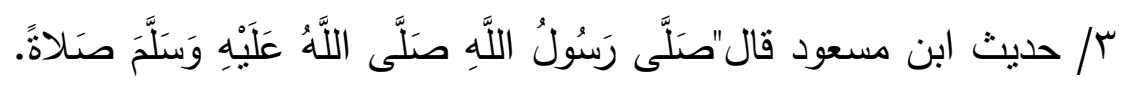

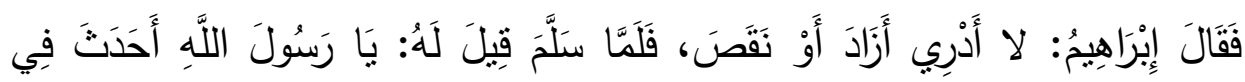

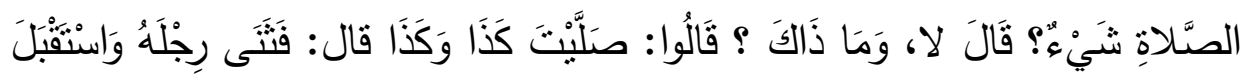

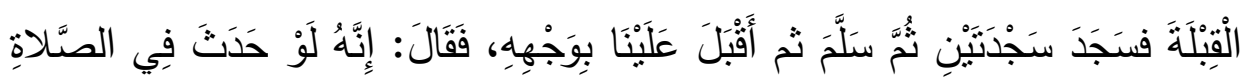

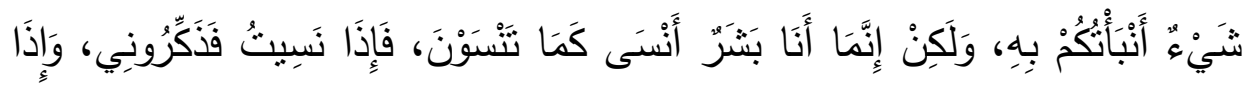

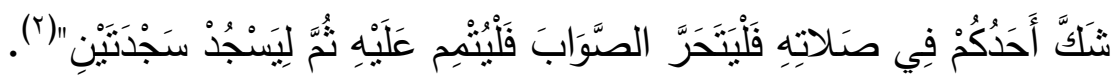
ع/ حديث أبي سعبد قال: قال رسول الله صلى الله عليه وسلم (إذا شك أحدكم في صلاته فلم يدر كم صلى ثناثاً أم أربعا فلبطرح الثك وليين على ما استيقن ثم يسجد سجدتين قبل أن يسلم فإن كان صلى خمساً شفعن لله صداته وإن كان صلى إنماماً لأربع كانت ترغيماً للشيطان) (َ). / حديث عمران بن حصين بنحو حديث أبي هربرة السابق وفيه: وَسَلَّمَ من ثَّلاثِ رَكعات فلما قيل لله صلى ركعة ثم سلم ثم سجد سجدتين ثم سلم (؟).

$$
\begin{aligned}
& \text { (') أخرجه مسلم في الصحيح في } 0 \text { - كتاب المساجد ومواضع الصلاة } 19 \text { - باب السهو في }
\end{aligned}
$$

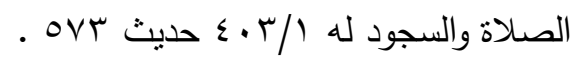

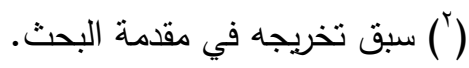

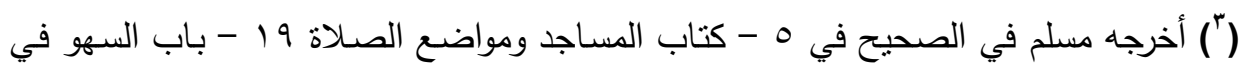

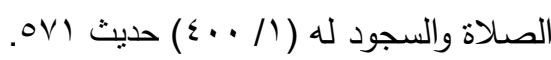

$$
\begin{aligned}
& \text { () أخرجه مسلم في الصحيح في ه - كتاب المساجد ومواضع الصدلاة } 19 \text { - - باب السهو في }
\end{aligned}
$$

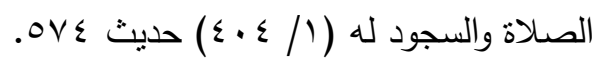




\section{مجلة معالم الدعوة الإسلامية المحكمة - العدد (السابع) - ذو الحجة جبع اهـ/ ديسمبر \& ا ـrم}

// حديث عبد الله بن بحينة أن النبي صلى الله عليه وسلم (قام من صلاة

الظهر وعليه جلوس فلما أنم صلاته سجد سجدتين يكبر في كل سجدة وهو جالس

قبل أن يسلم، وسجدهما الناس معه، مكان ما نسى من الجلوس (').

المطلب الثالث: حكم سجود السهو عند أصحاب المذاهب الأربعة

مع اتفاق الفقهاء جميعاً على مشروعية السهو إلا أنهم اختلفوا في حكمه فمنهم من أوجبه، ومنهم من برى أنه سنة ومنهم من برى أنه يكون واجباً إذا كان

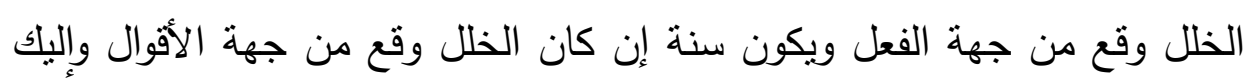
أقوالهم:

أولاً: الحنفية قالوا: يجب سجود السهو على الصحيح، يأثث المصلي بتركه، ولا تبطل صلاته؛ لأنه ضمان فائت، وهو لا يكون إلا واجباً، وهو يرفع الواجب من لن

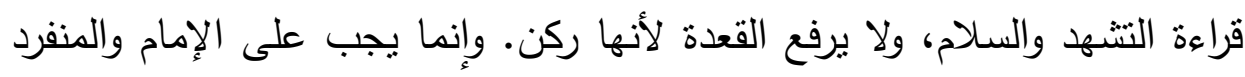
أما المأموم (المقتدي) إذا سها في صلاته فلا يجب عليه سجود السهو فإن حصل السهو من إمامه وجب عليه أن يتابعه وإن كان مدركاً أو مسبوقاً في حالة الإقتداء وإن لم يسجد الإمام سقط عن المأموم لأن متابعته لازمة لكن المسبوق يتابع في السجود دون السلام.

ووجوب سجود السهو إذا كان الوقت أو الحالة، صالحاً للصلاة فلو طلعت الثمس بعد السلام في صلاة الفجر أو أحمرت الثمس في صلاة العصر سقط عنه سجود السهو لأن السهو جبر للنقص المنتكن كالقضاء ولا يقضي الناقص(r).

(') أخرجه البخاري في الصحيح في بr كتاب ما جاء في السهو ع باب من يكبر في سجدتي السهو

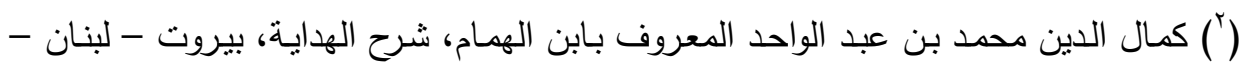

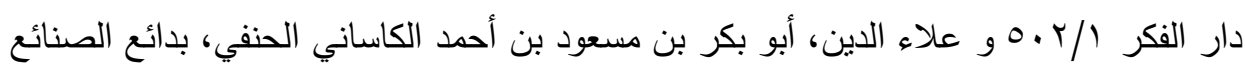

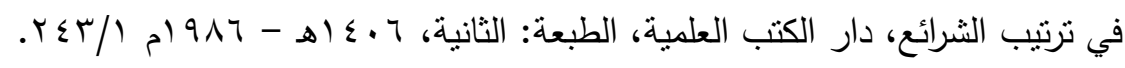


فالأحناف يرون وجوب سجود السهو مع عدم شروطه في الصلاة فحملوا أفعاله صلى الله عليه وسلم في السجود على الوجوب. ثانياً: المالكية قالوا: سجود السهو واجب وفاقا لأبي حنيفة وقيل سنة وفاقاً للثافعي وقيل بوجوب القبلي خاصة فإن نسي البعدي سجد منى ذكره ولو بعد شهر وإن نسي القبلي سجد ما لم يطل أو يحدث فإن طال أو أحدث بطلت الصلاة على المشهور وقيل إنما تبطل إن كان عن نقص فعل لا قول فإن ذكر البعدي في صلاة تمادى وسجد بعدها وإن ذكر القبلي فهو كذاكر صلاة في صلاة('). فرق المالكية بين سجود السهو في الأفعال وبين سجود السهو للأقوال، فتأكد عند الإمام مالك الأفعال أكثر من الأقوال. يقول ابن رشد"وفرق الإمام مالك - رحمه الله: بين السجود للسّهو في الأفعال، وبين السّّود للسّهو في الأقوال، وبين الزيادة والنّقصان فقال. سجود السّهو الذي يكون للأفعال الناقضة واجب؛ وهو عنده من شروط صحّة الصلاة وهذا في المشهور. وعنه: أنّ سجود السهو للنقصان واجب، وسجود الزيادة

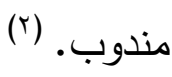
ثالثاً: الثافعية قالوا: سجود السهو سنة للإمام والمنفرد أما المأموم فلا يسجد للسهو نفسه خلف إمامه ويحتمل الإمام عنه سهوه في حال قدوته كما يتحمل عنه القنوت وغير أما المحدث فلا يتحمل عنه ولا يلحقه سهوه إذ لا قدرة في الحقيقة.

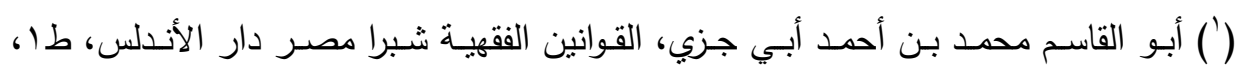

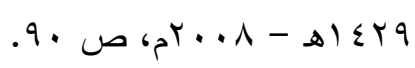

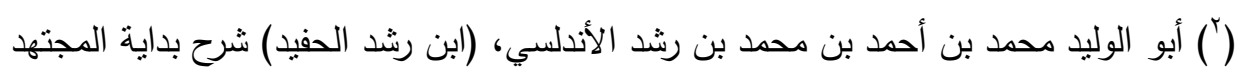

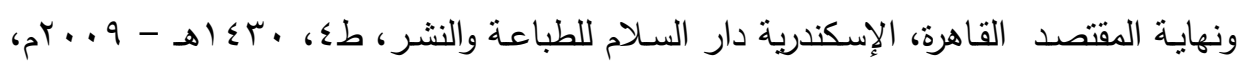


ويجب سجود السهو في حالة واحدة وهي متابعة المقتدي لإمامه ولو كان مسبوقاً فإن سجد لسهو وجب أن يسجد تبعاً لإمامه. لأن المتابعة لازمة فإن لم يسجد بطلت صلاته، ووجب عليه إعادتها إن لم يكن قد نوي المفارقة إلا أن علم المأموم

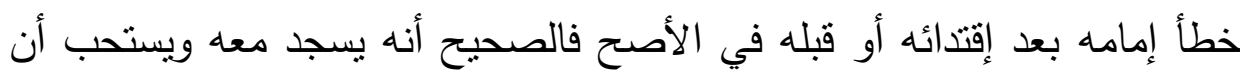
يسجد في آخر صلاته لأنه محل السهو الذي لحقه. (') ونأكيداً لسنية السهو عند الثافعية يقول الرملي:"سجود السهو سنة مؤكدة، ولو في نافلة سوى صلاة الجنازة، وشمل ذلك ما لو سها في سجدة التلاوة خارج الصلاة فيسجد للسهو، ولا مانع من جبران الثيء بأكثز منه خلافاً لبعض المتأخربن، ومثلها سجدة الثكر، وإنما لم يجب؛ لأنه ينوب عن المسنون دون المفروض، والبدل إما كمبدله أو أخف منه"(r)، فالثافعية حملوا أفعاله وأقواله في وله سجود السهو على الندب. رابعاً: الحنابلة قالوا: سجود السهو تارة يكون واجباً وتارة يكون مسنوناً وتارة يكون مباحاً وذلك لاختلاف سببه على ما يأتي وهذا بالنسبة للإمام والمنفرد أما المأموم فيجب عليه متابعة إمامه في السجود ولو كان مباحاً فإن لم يتابعه بطلت صلاته فإن نرك الإمام أو المنفرد السجود فإن كان مسنوناً أو مباحاً فلا شيء في تركه وإن كان واجباً فإن كان الأفضل فيه أن يكون قبل السلام كأن يكون لترك واجب دن واجبات الصلاة سهوا بطلت الصلاة بتركه عمدا أما إذا تركه سهواً وسلم فإن تذكره عن قرب عرفاً أتى به وجوباً ولو تكلم أو انحرف عن القبلة ما لم يحدث

(') أبو زكريـا محي الدين يحيى بن شـرف النووي: روضـة الطالبين وعمدة المفتين، تحقيق:

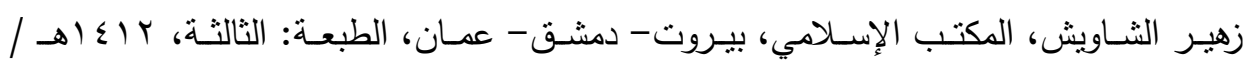
. أن

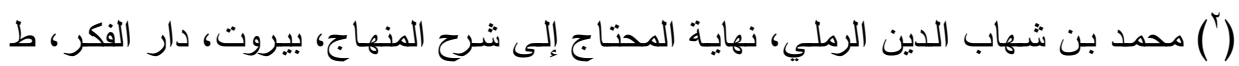
$.7 T / Y$ م) $918-ه \mid$ 
أو يخرج من المسجد وإلا سقط عنه ولا تجب عليه إعادة الصلاة كما إذا طال الزمن عرفاً وإن ترك جهلاً لم تبطل صلاته وأما إذا كان الأفضل فيه أن يكون بعد السلام - وهو ما إذا كان سببه السلام سهواً قبل تمام الصلاة - فإن تركه عمداً أثث ولا تبطل صلاته وإن نركه سهواً وتذكره في زمن قريب عرفاً وجب الإتبان به وإلا أثن والصلاة صحيحة وإن طال الزمن عرفاً أو أحدث أو خرج من المسجد سقط عنه وإن نركه جهلاً فلا إثث عليه وصحت وإن صلاته('). والراجح من هذه الأقوال أن سجود السهو سنة وذللك لحديث أبي سعيد الخدري الذي ورد ذكره سابقاً وفيه صرف الوجوب والندب والله أعلم.

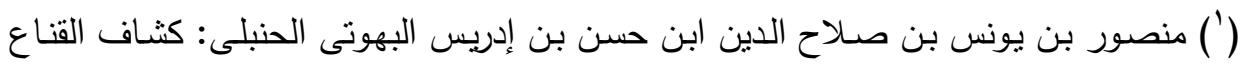

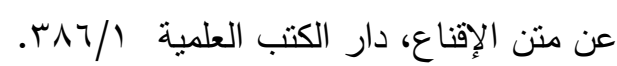




\section{المطلب الرابع: أسباب سجود السهو}

اختلف الفقهاء في تعداد أسباب سجود السهو مع اتفاقهم أنها لا تخرج عن ثلاثة أسباب وهي: إما الزيادة أو النقص أو الثك وإليك بيان هذه الأسباب في المذاهب مع قليل من التفصيل: أولاً: مذهب الحنفية

قالوا:"يسجد للسهو بترك شيء عمداً أو سهواً أو زيادة شيء سهواً أو تغيير محله

$$
\text { سهواً في الأحوال الآتية: }
$$

( ) نرك قراءة الفاتحة أو أكثرها في الركعتين الأوليين من الفرض.

Y) ترك سورة أو ثلاث آيات قصار أو آية طويلة بعد الفاتحة في الركعتين

$$
\text { الأوليين من الفريضة. }
$$

r) مخالفة نظام الجهر والإسرار : فإن جهر في الصلاة السرية نهاراً وهي الظهر والعصر ، وخافت في الصلاة الجهرية ليلاً وهي الفجر والمغرب والعشاء، سجد

$$
\text { للسهو - }
$$

ع) ترك القعدة الأولى للتشهد الأول في صلاة ثلاثية أو رباعية.

$$
\text { 0) ترك التشهد في القعدة الأخيرة }
$$

T) عدم مراعاة التزتيب في فعل مكرر في ركعة واحدة، وهو السجدة الثانية في ركعة، فلو سجد سجدة واحدة سهواً، ثم قام إلى الركعة التالية، فأداها بسجدتيها، ثم تذكر السجدة المنزوكة في آخر صلاته، فسجدها، فيجب عليه سجود السهو بترك التزتيب؛ لأنه ترك الواجب الأصلي ساهياً، فوجب سجود السـهو •

أما عن عدم رعاية الترتيب فيما لا يتكرر كأن أحرم فركع ثم رفع ثم قرأ الفاتحة والسورة فيوجب عليه إعادة الركوع ويسجد للسهو وإذا شك في صلاته (من لم يكن ذللك) أي الثك (عادة له) وقيل من لم يثك في صلاة قط بعد بلوغه وعليه 
أكثر المشايخ، كما صلى استأنف بعمل منافي بالسلام قاعداً أولى لأنه المحلل وإن

كثر شكه عمل بغالب ظنه إن كان له ظن إلا أخذ بالأقل لتيقنه" (1). ثانياً: مذهب المالكية: قالوا: يسجد للسهو بأسباب ثثلاثة: نقص فقط، وزيادة فقط،

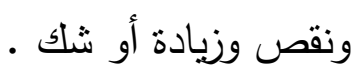

أما التقص: فهو ترك سنة مؤكدة داخلة في الصلاة سهواً أو عمداً، كالسورة إذا تركها عن محلها سهواً، أو ترك سنتين خفيفتين فأكثر كتكبيرتين من تكبيرات الصلاة سوى تكبيرة الإحرام، أو ترك تسميعتين أو تكبيرة وتتميعة -.. فإن نقص ترس ركناً عمداً بطلت صلاته، وإن نقصه سهواً أجبره ما لم يفت محله، فإن فات ألغى الغئ الركعة وقضاها.

وأما الزيادة: فهي زيادة فعل غير كثير ليس من جنس الصلاة، أو من جنسها. مثال الأول: أكل خفيف أو كلام خفيف سهواً. ومثال الثاني: زيادة ركن فعلي من أركان الصلاة كالركوع والسجود، أو زيادة بعض من الصلاة كركعة أو ركعتين، أو أن يسلم من اثثتين. وبسجد للزيادة بعد

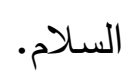
أما زيادة القول سهواً: إن كان من جنس الصلاة فمغتفر ، وإن كان من غيرها سجد له. وأما الزيادة والنقص معاً:فهو نقص سنة ولو غير مؤكدة، وزيادة ما تقدم في

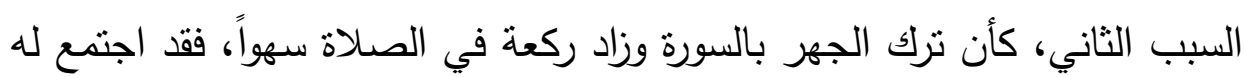

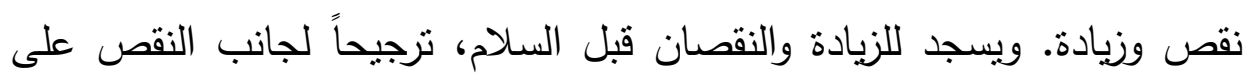
الزيادة.

\footnotetext{
(') كمال الدين محمد بن عبد الواحد السيواسي المعروف بابن الهمام: شرح فتح القدير ، دار

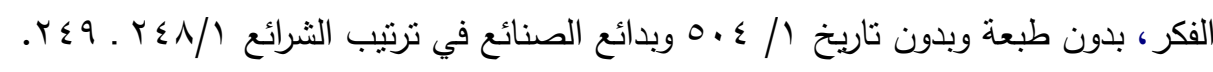
raA
} 


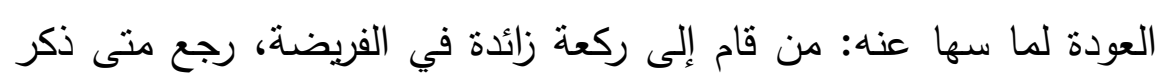

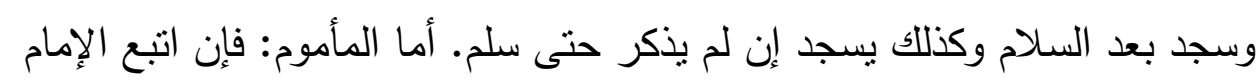

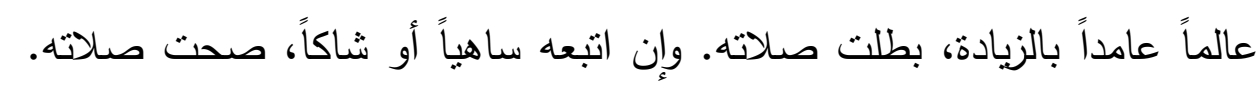

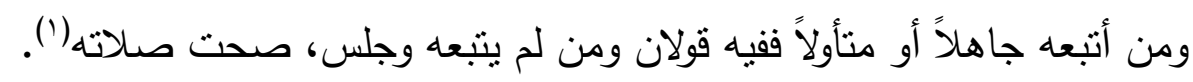

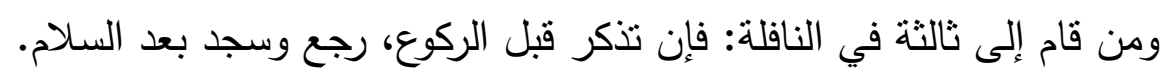

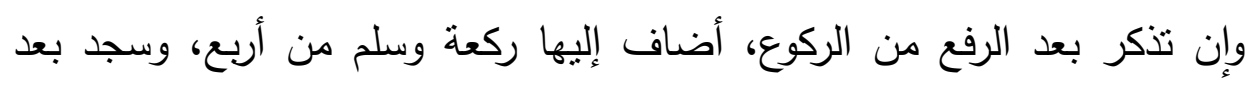
السلام لزيادة الركتنين.

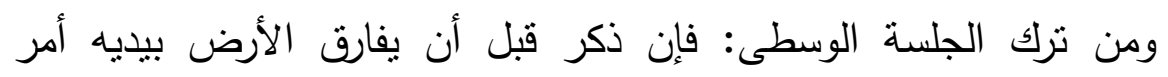

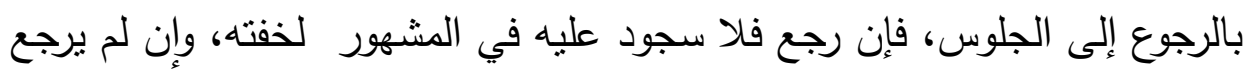

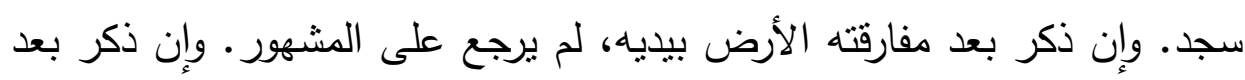

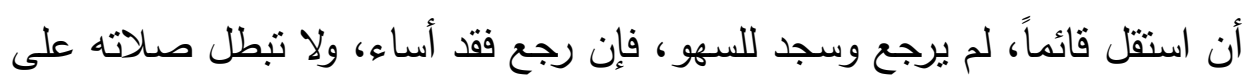

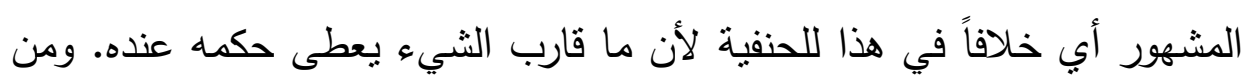

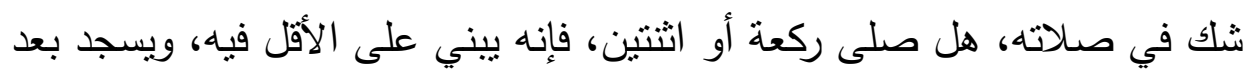

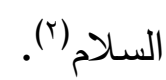

هذا هو الثنك العادي أما من استتكحه الثك في السهو فعندهم [أي المالكية] فليله عنه ولا إصلاح عليه، أي ينتهي عنه ولا يلتقت إليه وصلاته صحيحة.

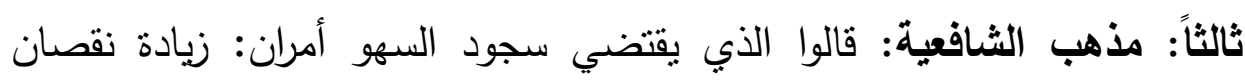

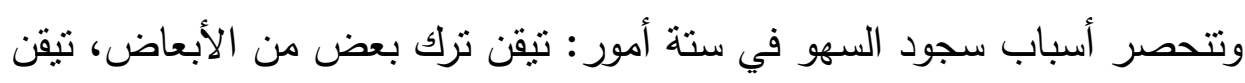

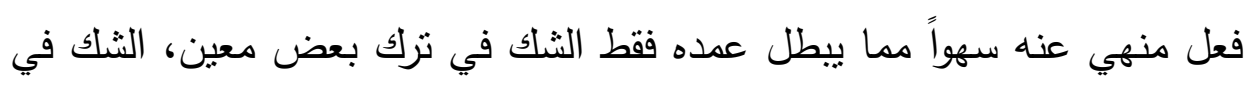

(') مالك بن أنس بن مالك بن عامر الأصبحي المدني: الددونة، دار الكتب العلمية، الطبعة

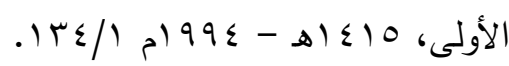

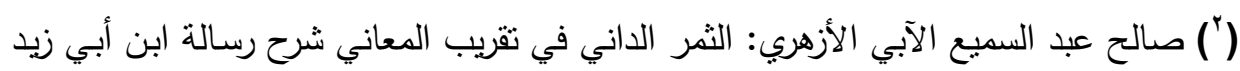

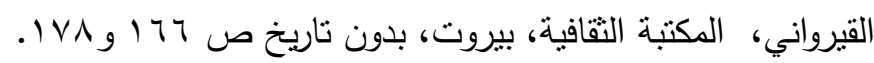


فعل منهي عنه مع احتمال الزيادة نقل مطلوب قولي لغير محله بنيته، الإقتداء بمن يترك أحد الأبعاض، الأول: ترك الإمام أو المنفرد عمداً أو سهواً سنة مؤكدة وقيل تسمى بأبعاض الصلاة وهي ستة: وهي التشهد الأول، وقعوده، والقنوت في الصبح وفي آخر الوتر في النصف الثاني من رمضان، والقيام للقنوت، والصلاة على النبي صلّى الله عليه وسلم في التشهد الأول، والصلاة على الآل في التشهد

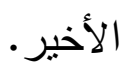

الثاني: نقل ركن قولي لغير محله: كأن يعيد الفاتحة في الجلوس، وأن بسلم في غير موضع السلام ناسياً، وكذلك نقل السنة القولية كأن يقرأ السورة في غير موضع القراءة، فيسجد للسهو؛ لأنه قول في غير موضعه، فصار كالسلام. ويستنىى قراءة السورة قبل الفاتحة، فلا يسجد لها.

الثالث . فعل شيء سهواً، يبطل عمده فقط: كتطويل الركن القصبر في الأصـح، بأن يطيل الاعتدال أو الجلوس بين السجدتين. ومثله الكلام القليل سهواً،

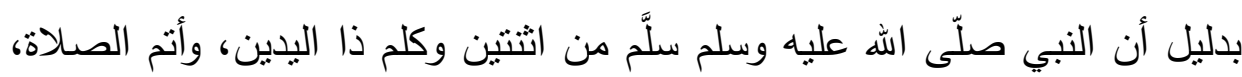
وسجد سجدتين، وأما ما يبطل عمده وسهوه ككلام كثير وأكل، فيبطل الصلاة ولا يسجد لله في الأصح، وأما ما لا ييطل عمده ولا سهوه كالتفات بالعنق ومشى خطوتين، فلا يسجد لسهوه ولا لعدده.

الرابع الثك في الزيادة: فلو شك أصلى ثلاثاً أم أربعاً، أتى بركعة وسجد، وهده والأصح أنه يسجد وإن زال شكه قبل سلامه، وكذلك يسجد لما يصليه متردداً واحتمل كونه زائداً للتردد في زيادته وإن زال شكه قبل سلامه ولو شك بعد السلام في ترك فرض يؤثر على المشهور •

الخامس: الإقتداء بمن في صلاته خلل: ولو في اعتقاد المأمون، كالإقتداء بمن بيترك في صلاته على النبي صلى الله عليه وسلم في التشهد الأول فيسجد بعد سلام الإمام وقبل سلام نفسه. 


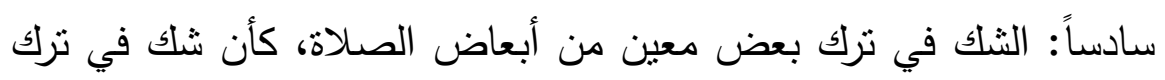

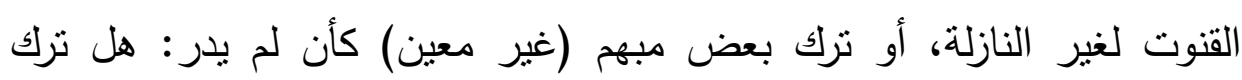

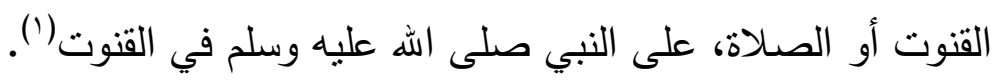

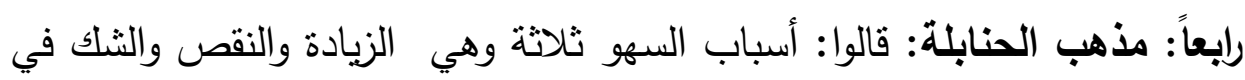

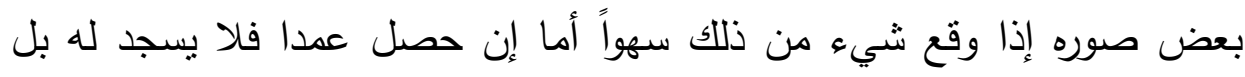

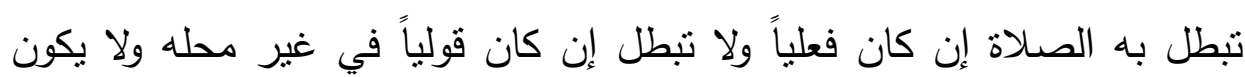

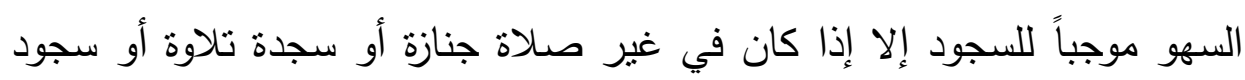

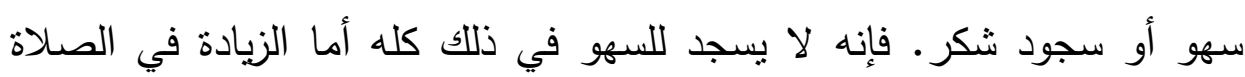

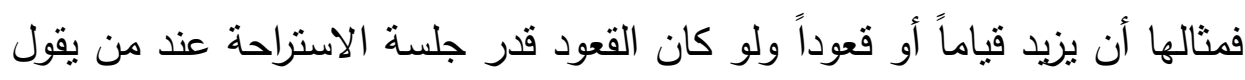

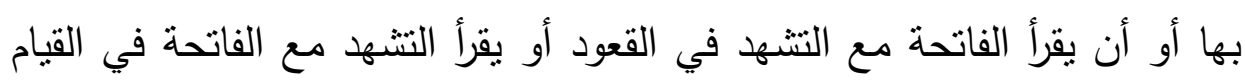

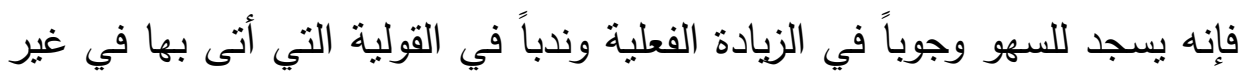

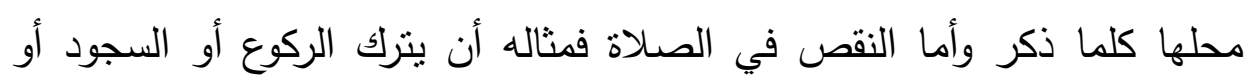

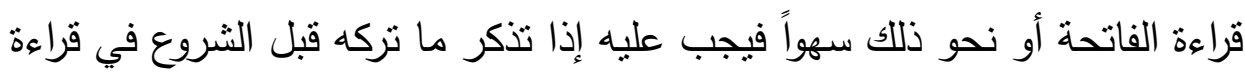

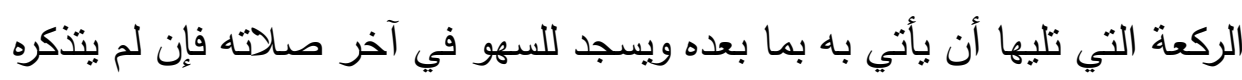

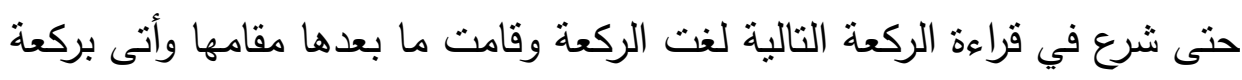

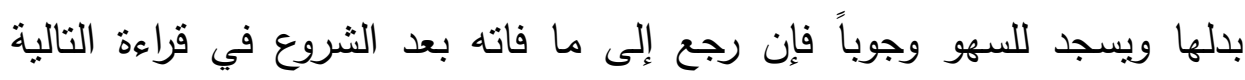

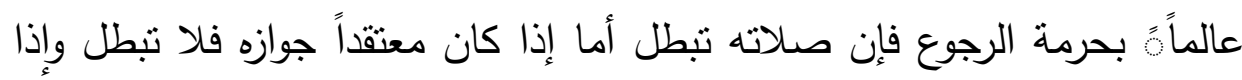

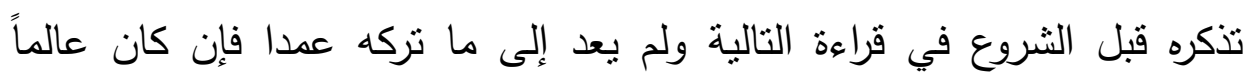

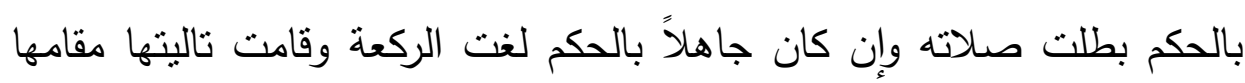
وأتى بركعة بدلها وسجد للسهو وجوباً: أما إذا لم يتذكر ما فاته إلا بعد سلامه الها

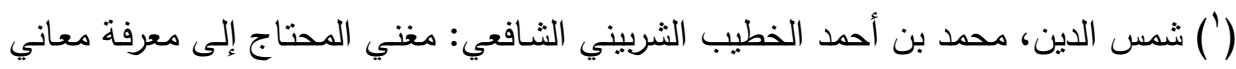

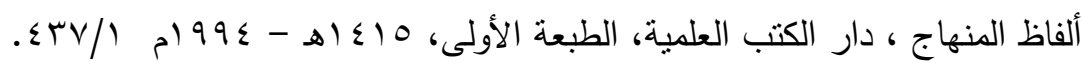

$$
\begin{aligned}
& \text { r. }
\end{aligned}
$$


فيجب عليه أن يأتي بركعة كاملة إن كان ما نركه من غير الركعة الأخيرة فإن إنان

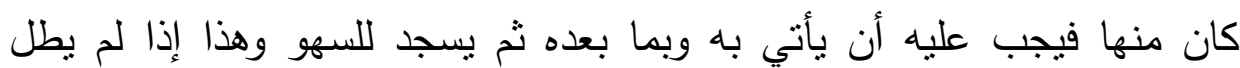

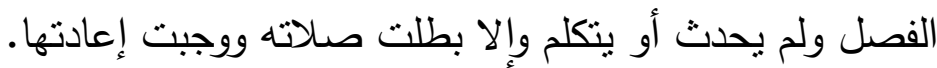

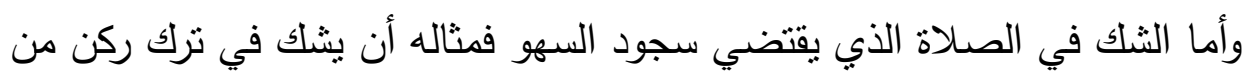

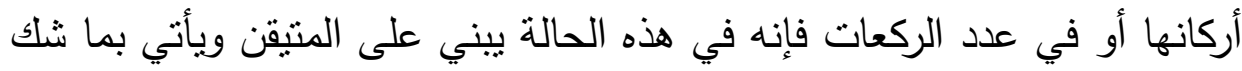

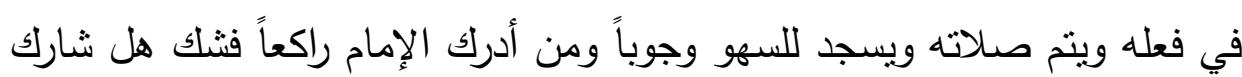

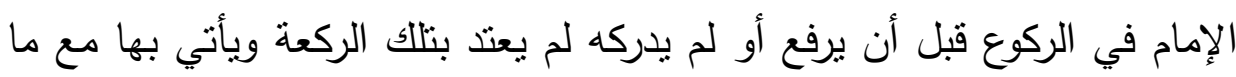

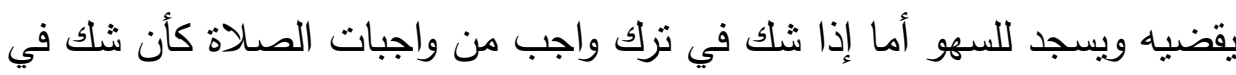

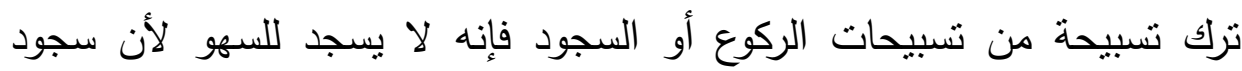

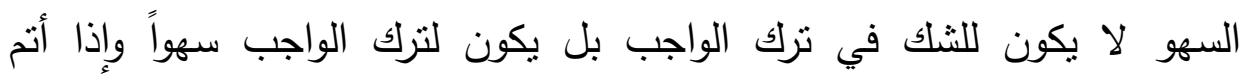

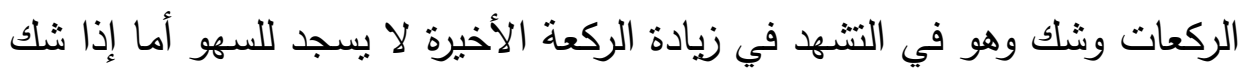

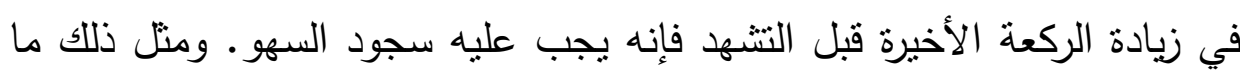
إذا شك في زيادة سجدة على التقصيل المتقدم ('). خلاصة أسباب سجود السهو:

سجود السهو يكون من زيادة في الصلاة أو من نقص منها أو من شك في الزيادة

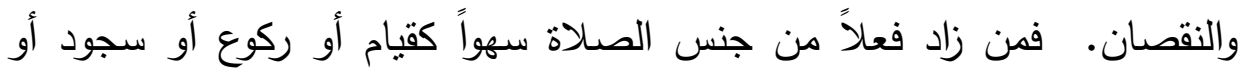

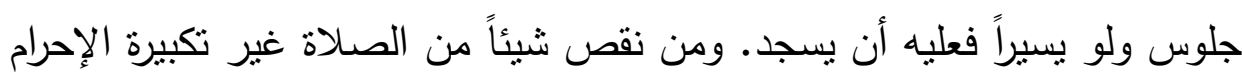

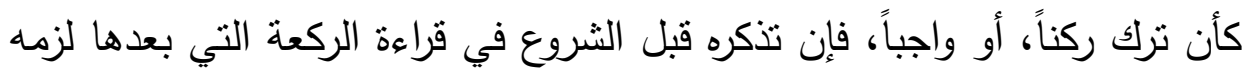

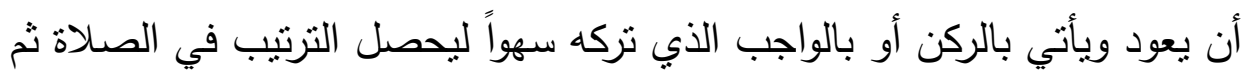

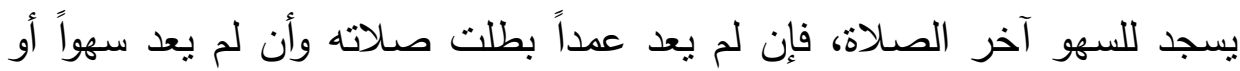

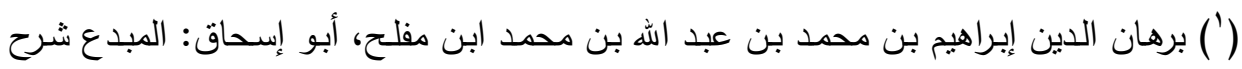

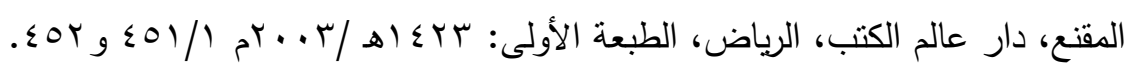
$r \cdot r$ 
جهلاً بطلت الركعة فقط وصارت ملغاة كأن لم تكن وكذلك إذا لم يتذكر الركن أو الواجب حتى شرع في قراءة الركعة التالية، فإن عليه أن بعتبر الركعة التي نقصت ركناً أو واجباً ملغاة وتحل محلها الركعة التي بعدها وبسجد للسهو . ومن نسي التشهد الأول، وقام للثالثة جلس له ما لم يستو قائماُ فأن تم قيامه فلا يرجع ويسجد للسهو وإن رجع قيل يكرهوقيل تبطل الصلاة والأول أرجح. ومن ترك سنة من سنن الصلاة سهواً أو جهراً فإن سجود السهو بالنسبة له سنة وليس واجباً. يجب على المأمون أن يتابع إمامه في سجود السهو، وإن لم يكن مقتدياً به وقت سهوه. وإذا سها المأمون أثناء إقتدائه بإمامه فلا سجود عليه لأن الإمام يتحمل عنه سهوه، غير أن المسبوق يسجد مع الإمام ولا يسلم بل يقوم لقضاء ما فاته. إذا سها المأموم أثتاء اقتائه بإمامه فلا سجود عليه لأن الإمام يتحمل عنه سهوه. من شك في صلاته فلم يدر كم عدد ما صلاه، فإن عليه أن يبني على الأقل المتيقن، ثم يسجد للسهو فمن كان لا يدري هل صلى ثناثناً أو أربعاً فإن إن

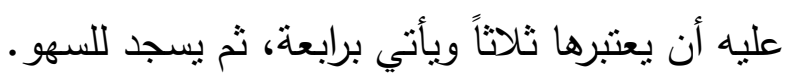
ومن نسي أن عليه سجود سهو فسلم ولم يسجد ثم تذكر سجد للسهو ما دام في المسجد ولو تلكم، إلا إذا حصل فاصل طويل بحسب العرف ('). 


\section{المطلب الخامس: مواضع سجود السهو}

اختلف العلماء في مواضع السهو على خمسة أقوال:

ذهب الأحناف إلى أن محله بعد السلام، يقول الكاساني:"فمحله المسنون

بعد السلام عندنا، سواء كان السهو بإدخال زيادة في الصدلاة أو نقصان فيها"('). وفرقت المالكية فقالت: إن كان السجود لنقصان كان قبل السلام، وإن كان لزيادة كان بعد السلام ومن نقص وزاد سجد قبل السلام (r).

وذهبت الثافعية إلى أن سجود السهو موضعه أبداً قبل السلام، يقول النووي:"وفي محله ثلاثة أقوال أظهرها: قبل السلام. والثاني: إن سها بزيادة، سجد بعد السلام، وإن سها بنقص، سجد قبله. والثالث: أنه يتخير ، إن شاء قبله، وإن شاء بعدهوالأول: هو الجديد (r). بونان وقالت الحنابلة:"ما كان من زيادة فهو بعد السلام؛ لحديث ذي اليدين، وما كان من نقصان أو شك كان قبله؛ لحديث ابن بحينة وأبي سعيد، وعنه رواية أخرى أن جميعه قبل السلام"(£). وخلاصة أقوال الفقهاء في مواضع سجود السهو: نجد أن الأحناف ذهبوا إلى رأي واحد هو أن موضعه بعد السلام سواء أكان من زيادة أو نقصان، أما بالنسبة

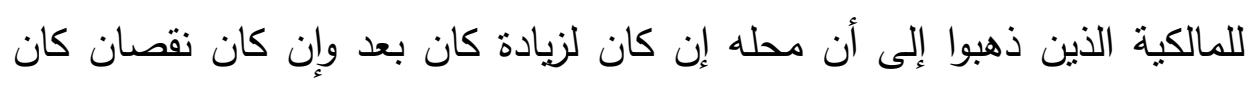
قبل، فاتفق معهم الثافعية في مذهبهم القديم قبل وبعد، وخالفوهم في مذهبهر الجديد وهو أن موضعه قبل السجود، وكذا الحنابلة فقد اتفقوا مع المالكية أيضاً.

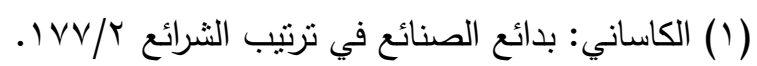

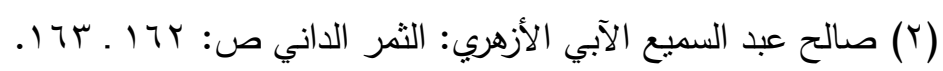

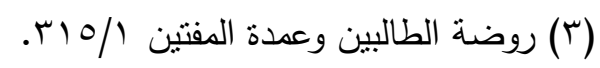

(ع) أبو محمد موفق الدين عبد الله بن أحمد ابن قدامة المقدسي: الكافي في فقه الإمام أحمد،

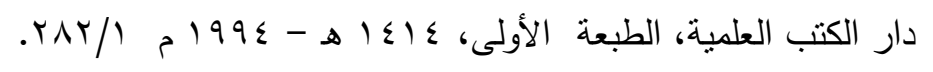
r. 
والذي يترجح للباحث من هذه الأقوال مذهب الإمام مالك لأنه فيه جمع ما

ورد في الأحاديث التي ذكر فيها أن النبي صلى الله عليه وسلم سجد بعد السلام

وكذلك قبله.

يقول شيخ الإسلام ابن تيمية:"والصحيح الذي تجنمع عليه النصوص المتقدمة التفريق بين الزيادة والنقص وبين الثك مع التحري، والثك مع البناء على اليقين وهو اختياره إذ قال: وهذا إحدى الروايات عن أحمد ومذهب مالك قريب منه، وليس متلكه فإن هذا مع ما فيه من استعمال النصوص كلها ففيه الفرق المعقول وذلك أنه: إذا كان في نقص - ترك التشهد الأول - احتاجت الصلاة إلى جبر وجابرة يكون قبل السلام لتمم به الصلاة فإن السلام هو تحليل من الصدلاة. وإذا كان من زيادة - كركعة - لم يجمع في الصلاة بين زيادتين بل يكون السجود بعد السلام لأنه إرغام للشيطان، بمنزلة صلاة مستقلة جبر بها نقص ثثلاته فإن صلى الله عليه وسلم جعل السجدنين كركعة. وكذلك إذا شك وتحرى فإنه أتم صلاته، وإنما السجدان لترغيم الثيطان فيكون بعد السلام. وكذلك إذا سلم وقد بقي عليه بعض صلاته ثم أكملها فقد أثمها والسلام منها زيادة والسجود بعد ذلك السلام لأنه إرغام للتشيطان. وأما إذا شك ولم يتبين له الراجح فهنا إما أن يكون صلى أربعاً أو خمساً فإن كان صلى خمساً فالسجدتان يشفعان له صلاته ليكون كأنه قد صلى ستاً لا خمساً وهذا إنما يكون قبل السلام. 
قال ابن تيمية - رحمه الله - فهذا القول الذي نصرناه هو الذي يستعمل فيه

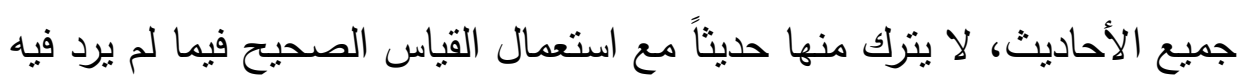

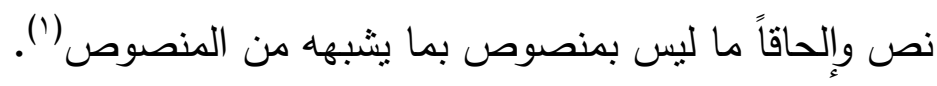

(1) أحمد بن عبد الحليم بن تيمية الحراني أبو العباس: مجموع الفتاوى، مجمع الملك فهر

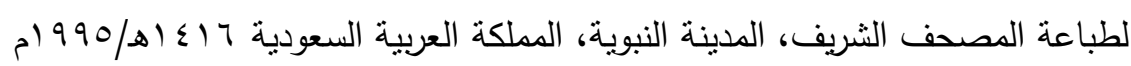
.rs/rr $r \cdot T$ 


\section{المطلب السادس: صفة سجود السهو عند الأئمة الأربعة}

قال الحنفية: وصفته: أن يسجد سجدتين بعد أن يسلم عن يمينه التسليمة الأولى فقط، ثم يتشهد بعدها وجوباً، ويأتي بالصلاة على النبي صلى اله عليه وسلم والدعاء في قعدة السهو لأن الدعاء موضعه آخر الصلاة. ودليلهم على صفته حديث عمران بن حصين أَنَّ النَّبَِّ صنََّّى الله عَلَيْهِهِ وَسَلَّمَ

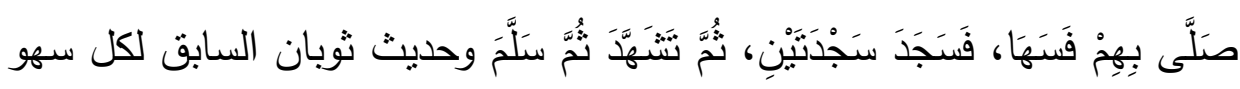
سجدان بعد التسليم. والمذكور في هذا الموضوع هو الصحيح الراجح عند

وقال المالكية: وبسجد سجدتين جالساً بينها، وبتشهذ استتاناً، ولا يدعو ولا يصلي على النبي صلى الله عليه وسلم ثم يسلم وجوباً، فنكون واجباته خمسة: وهي النية، والسجدة الأولى، والثانية، والجلوس بينهما، والسلام، لكن السلام واجب ولب غير شرط، وأما التكبير والتشهر بعده فسنة (r).

وقال الثافعية: وصفته: سجدتان كسجود الصلاة في واجباته ومندوباته(ץ). وقال الحنابلة: وصفته: أن يكبر للسجود والرفع منه، سواء أكان قبل السلام أم بعده، ثم يسجد سجدتين كسجود الصلاة، فإن كان السجود بعدياً يأني بالتشهد كتشهد الصلاة قبل السلام ثم يسلم، وإن كان قبلياً لم يتشهد، ويسلم عقبه. ويقول في سجود السهو ما يقول في سجود صلب الصلاة لأنه سجود مشروع في الصلاة أثبه سجود صلب الصلاة (؟)

(1) ابن عابدين، محمد أمين بن عمر بن عبد العزيز عابدين الدمشقي الحنفي: رد المحتار

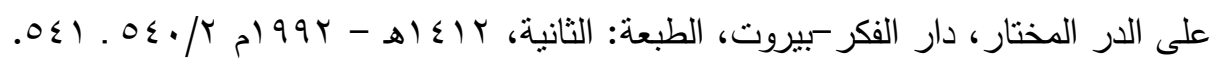

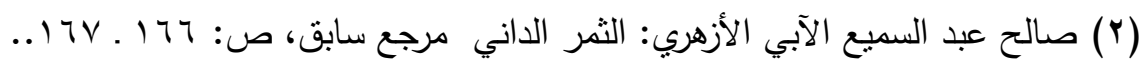

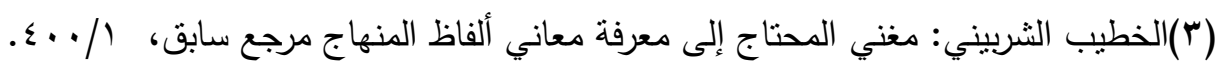

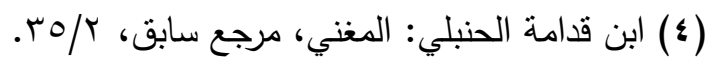


ولقد لخص ابن رشد صفة سجود السهو عند الأئمة الأربعة قائلاً: وأما صفة سجود السهو فإنهم اختلفوا في ذلك؛ فرأى مالك أن حكم سجدتي السهو إذا كانت بعد السلام أن يتشهد فيها ويسلم منها، وبه قال أبو حنيفة لأن السجود كله عنده بعد السلام، وإذا كانت قبل السلام أن بيتشهد لها فقط، وأن السلام من الصلاة هو سلام منها، وبه قال الثافعي إذ كان السجود كله عنده قبل السلام، وقد روي عن مالك أنه لا يتتهد للتي قبل السلام، وبه قال جماعة ـ قال أبو عمر : أما السلام من التي بعد السلام فتابت عن النبي صلى الله عليه وسلم. وأما التشهد فلا أحفظه

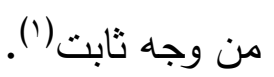
يقول مؤلف صحيح فقه السنة: لأهل العلم في هذه المسألة أربعة أقوال أصحها أنه لا يتشهد بعد سجدتي السهو لعدم ثثبته عن النبي صلى الله عليه وسلم وإنما اعتمد من قال به على ما روى من حديث عمران بن حصين (؟). 


\section{نتائج البحث:}

$$
\text { نلخصها في الآتي: }
$$

// المتروك بالسهو أنواع: فريضة، أو سنة، أو فضيلة أو هيئة، فلا يسجد إلا لواجب

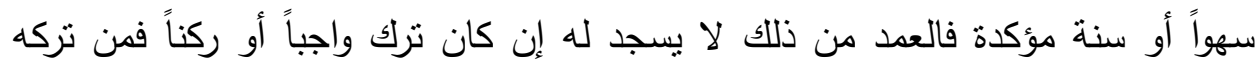
عمداً فالصلاة باطلة لا ينفع فيها سجود السهو أما إن كان سنة فالصداة صحئ صحيحة.

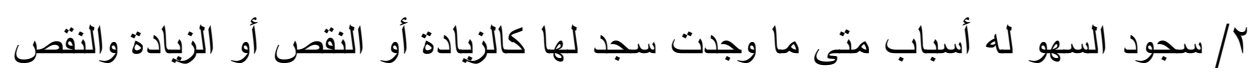
معاً وكذلك الثك. r/ من نرك سنة من سنن الصلاة سهواً أو جهراً فإن سجود السهو بالنسبة له سنة وليس واجباً.

ع / سجود السهو قد يقع بعد السلام وقد يقع قبل السلام وذلك حسب الزيادة والنقصان، ولا تبطل الصلاة إذا ترتب فيها سجود بعدي ولو تعمد ترك السجود البعدي وعليه أن يسجده ولو بعد سنين منى ما ذكره فلا يسقط بطول الزمن، أما السجود القبلي فلا تبطل الصلاة بتركه إذا ترتب عن سنتين خفيفتين فقط ويسجده إن لم يطل الزمن أو خرج من المسجد فإن طال الزمن أو خرج من المسجد سقط سجود السهو لخفته أما إن ترتب على ثنلاث سنن وخرج من المسجد أو طال الزمن أو حدث بطلت صناته هذا إذا تركه سهواً فإن تركه عمداً بطلت الصلاة بمجرد الترك.

إذا سها المأمون أثناء إقتدائه بإمامه فلا سجود عليه لأن الأمام يتحمل عنه سهوه. يجوز سجود السهو قبل السلام كما يجوز بعده باتفاق والخلاف في الأفضل. المسبوق يسجد مع الإمام إن كان السجود قبل السلام أما إن كان بعد السلام فلا يسجد بإن

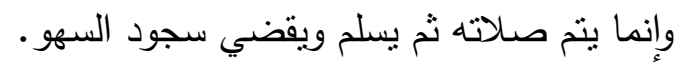

1/ حكم صلاة النافلة منل حكم صلاة الفريضة في سجود السهو عند عامة الفقهاء. T/ ينتهد الساهي لسجود السهو بعد السلام ولا يتشهد لسهوه قبل السلام والبعض برى أنه لا يتشهد مطلقاً. 
/ / ابن عابدين، محمد أمين بن عمر بن عبد العزيز عابدين الدمشفي الحنفي: رد المحتار على

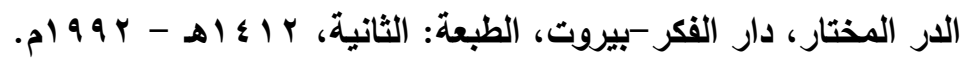
r/ أبو زكريا محيي الدين يحيى بن شرف النووي: روضة الطالبين وعمدة المفتين، تحقيق:

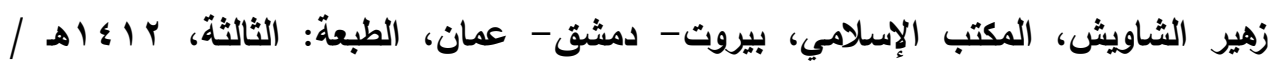
.01991 r/ أبـو القاسـم الحسن بـن محمد الراغب الاصفههاني: المفردات في غريب القرآن، المكتبـة التوفيقية.

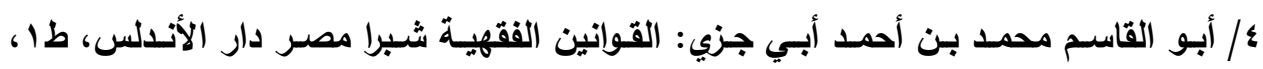

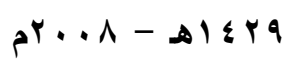
ه/ أبو مالك بن السيد سالم، صحيح فقه السنة، المكتبة التوفيقية سيدنا الحسين، طب ا، بلون تاريخ، ك/ أبو محمد عبد الوهاب بن علي بن نصر الثعلبي المالكي: التلقين في الفقه المالكي، تحقيق

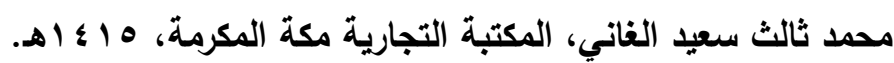

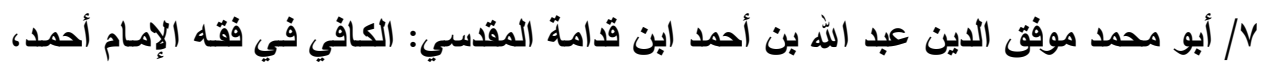

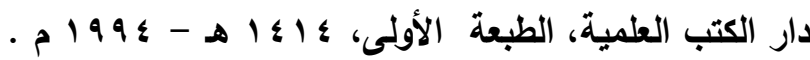

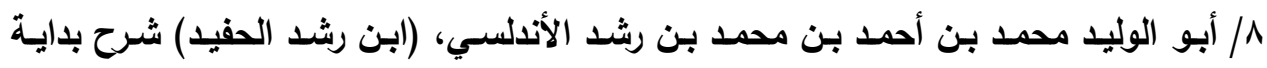

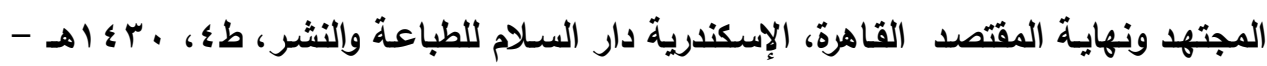
$\cdot r^{2} \cdot a$ 9 أحمد بن عبد الحليم بن تيميـة الحرانـي أبو العباس: مجموع الفتاوى، مجمـع الملك فهـ

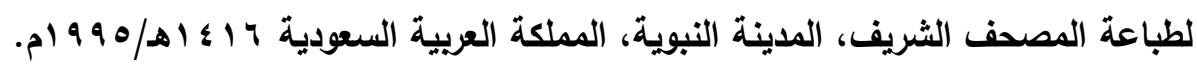

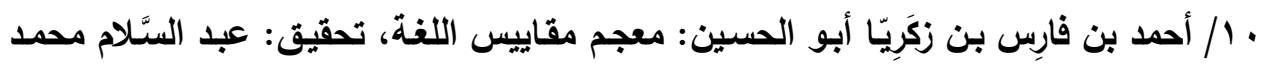

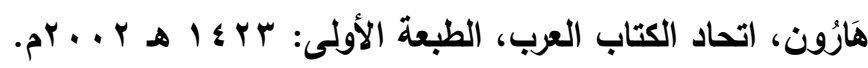

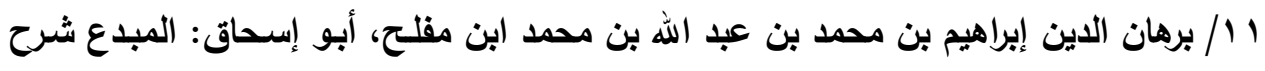

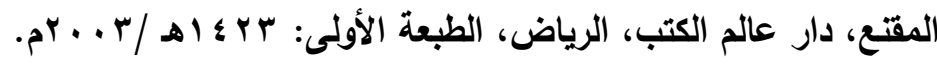
r / / حسن محمد أيوب فقه العبادات: بيروت، لبنان، دار الندوة ، الطبعة الرابعة. 
مجلة معالم الدعوة الإسلامية المحكمة - العدد (السابع) - ذو الحجة جبـع اهـ/ ديسمبر ع ا ـ rمم

با / خليل بن كيكلدي العلائي: ظم الفرائد لما تضمنه حديث ذي اليدين من الفوائد، مطبعة الأم

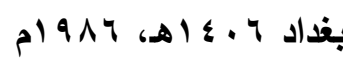

ـ ا شمس الدين محمد بن أحمد الشربينى: الإقناع في حل الفاظ ابى شجاع، دار المعرفة للطباعة والنشر والتوزيع، بلون طبعة وتاريخ. ه / شـمس الدين، محمـد بـ أحمد الخطيب الشـريني الشـافعي: مغتـي المحتـاج إلى معرفـة

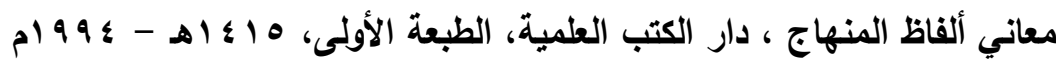
צ 1 / صالح عبد السميع الآبي الأزهري: الثمر الداني في تقريب المعاني شرح رسالة ابن أبي زيد القيرواني، المكتبة الثقافية، بيروت، بدون تاريخ. V / علاء الدين، أبو بكر بن مسعود بن أحمد الكاسـي الحنفي، بدائع الصنائع في ترتيب

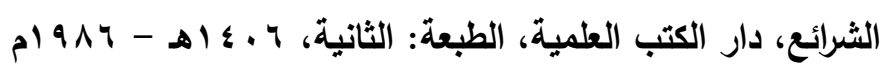
1 / كمال الدين محمد بن عبد الواحد المعروف بابن الهمام، شرح الهداية، بيروت - لبنان دار الفكر .

9 / / كمال الدين محمد بن عبد الواحد السيواسي المعروف بـابن الهمـام: شرح فتح القدير، دار الفكر، بلون طبعة ويدون تاريخ. • ب / مالك بن أنس بن مالك بن عامر الأصبحي المدني: المدونـة، دار الكتب العلميـة، الطبعة

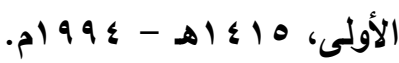

ا ب / محمد بن إسـماعيل أبو عبدالله البخـاري الجعفي: الجـامع الصـيح المختصر ، الناشـر: دار ابن

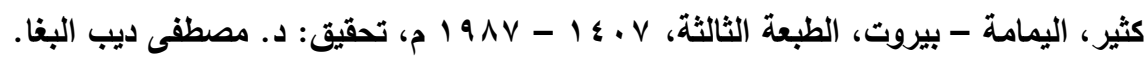

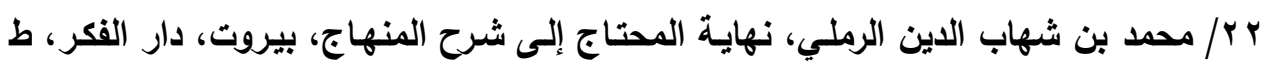
م) $9 \Lambda \varepsilon-\$ 1 \varepsilon \cdot \varepsilon$ r ץ / محمد بن صالح العثيمن، الثرح الممتع على زاد المستقنع دار ابن الرحيم ـ القاهرة ع ץ / محمد بن مكرم بن منظور المصري: لسان العرب دار صادر - بيروت، الطبعة الأولى ه ץ / مسلم بن الحجاج أبو الحسين القشيري النيسابوري: صديح مسـلم، التاشر: دار إحياء التراث العربي - بيروث، تحقيق: محمد فؤاد عبد الباقي. צ ץ / منصور بن يونس بن صلاح الدين ابن حسن بن إدريس البهوتى الحنبلى: كثاف القتاع عن متن الإقناع، دار الكتب العلمية. V V / يسري السبد محمد: جامع الفقه، دار الوفاء، المنصورة، بلون طبعة وتاريخ. 